\title{
DAYTIME VARIATIONS OF CHLOROPHYLL A FLUORESCENCE IN PAU D'ALHO SEEDLINGS ${ }^{1}$
}

\author{
Marcos Antonio Bacarin ${ }^{2}$, Emanuela Garbin Martinazzo ${ }^{3 *}$, Daniela $\mathrm{Cassol}^{4}$, Antelmo Ralph Falqueto $^{5}$ and \\ Diolina Moura Silva ${ }^{6}$
}

\footnotetext{
${ }^{1}$ Received on 09.07.2013 accepted for publication on 21.09.2016.

${ }^{2}$ Universidade Federal de Pelotas, Instituto de Ciências Biológicas, Departamento de Botânica, Capão do Leão, RS - Brasil. E-mail: <bacarin@ufpel.edu.br>.

${ }^{3}$ Universidade Federal de Pelotas, Programa de Pós-Graduação em Fisiologia Vegetal, Capão do Leão, RS - Brasil. E-mail: <emartinazzo@gmail.com>.

${ }^{4}$ Universidade Federal de Pelotas, Graduanda em Ciências Biológicas, Capão do Leão, RS - Brasil. E-mail:<danicassol@gmail.com>. ${ }^{5}$ Universidade Federal de Pelotas, Programa de Pós-Graduação em Fisiologia Vegetal, Capão do Leão, RS - Brasil. E-mail: <antelmofalqueto@hotmail.com>.

${ }^{6}$ Universidade Federal do Espírito Santo, Departamento de Ciências Biológicas, Vitória, ES - Brasil. E-mail: <biovegetal@terra.com.br>. *Corresponding author.
}

\begin{abstract}
Analysis of transient and modulated fluorescence of chlorophyll $a$ were made at one-hour intervals during an eight-hour period starting at 07:30h aiming to study mechanisms of photoprotection against high radiation and temperature in Gallesia integrifolia plants. Seeds were germinated inside plastic pots containing soil as substrate. At 120 days after emergence, chlorophyll fluorescence measurements were performed using Handy-PEA and FMS2 fluorometers. During the course of a day, an increase and a subsequent decrease in temperature and in photosynthetic active radiation were observed until 12:30h. Changes in transient kinetic curves of chlorophyll $a$ fluorescence were identified. This resulted in changes in JIP test parameters. An increase during the period of high radiation and temperature may be stressed in relation to variables related to dissipation flux and appearance of positive -K and - $\mathrm{L}$ bands. Considering the modulated fluorescence, high values of nonphotochemical quenching coefficients associated with lower values of effective photochemical efficiency of the photosystem II (FV'/ FM') and current photochemical efficiency of PSII ( $\varphi$ PSII) could be observed during early morning. This was probably the result of an inhibition of the biochemical phase of photosynthesis. It can be concluded that Gallesia integrifolia decrease its photochemical activity with the increase in the photosynthetic active radiation, demonstrating a photoinhibitory effect under high irradiance conditions, but without irreversible damages to the photosynthetic apparatus.
\end{abstract}

Keywords: Gallesia integrifolia; Photosynthetic active radiation; JIP test.

\section{VARIAÇÕES DIURNAS DA FLUORESCÊNCIA DA CLOROFILA A EM MUDAS DE PAU D'ALHO}

\begin{abstract}
RESUMO - Análises das fluorescências transiente e modulada da clorofila a, foram realizadas em intervalos de uma hora, durante o periodo de oito horas, iniciando-se as 07h30min, com o objetivo de estudar mecanismos de fotoproteção à elevação da radiação e temperatura, em plantas de Gallesia integrifolia. Sementes foram dispostas para germinar em vasos de polietileno contendo solo como substrato. Aos 120 dias após a emergência, determinações da fluorescência da clorofila foram realizadas com o uso dos fluorômetros Handy-PEA e FMS2. Durante o transcorrer do dia foi observada elevação na temperatura e na radiação fotossinteticamente ativa até as 12:30h com posterior queda. Identificou-se alteração nas curvas de cinética transiente da fluorescência da clorofila a o que resultou em alteração nos parâmetros de teste JIP, podendo ser destacado a elevação, durante o periodo de alta radiação e temperatura, nas variáveis relacionadas ao fluxo de dissipação, juntamente
\end{abstract}


com o aparecimento das bandas -L e-K positivas. Para a fluorescência modulada destacam-se altos valores dos coeficientes de extinção não fotoquímico associados aos menores valores da eficiência fotoquímica efetiva do fotossistema II ( $\left.F V^{\prime} / F M^{\prime}\right)$ e eficiência fotoquímica atual do FS II ( $\left.\varphi P S I I\right)$ no início da manhã, resultado provavelmente de uma inibição da fase bioquímica da fotossíntese. Pode-se concluir que as plantas de pau d'alho apresentam decréscimo na atividade fotoquímica com o incremento da radiação fotossinteticamente ativa, demonstrando um efeito fotoinibitório sob condições de alta irradiância contudo, sem dano irreversível ao aparato fotossintético.

Palavras chave: Gallesia integrifólia; Radiação fotossinteticamente ativa; Teste JIP.

\section{INTRODUCTION}

Gallesia integrifolia (Spreng.) Harms belongs to the Phytolaccaceae family and is naturally present in several Brazilian states, from Ceará (north) to Paraná (south). It is a large tree species common in Atlantic rain and semideciduous forests. It is a pioneer plant with a fast growth, optimal for a heterogeneous reforestation (LORENZI, 2004).

The use of native species for the restoration of devastated natural forests generates the need for production of seedlings as well as knowledge on the performance of such seedlings in the field. Light conditions imposed in the field after transplanting seedlings affect growth, morphology and chlorophyll content (HUSSNER et al., 2011) and may cause damage to the photosynthetic apparatus. Thus, the interaction of radiation with plants plays a key role in the growth and development of plants.

The functioning of the photosynthetic apparatus is a key indicator of physiological plant growth in a given environment (FRANCO, 2004). Currently, several methods have been used to analyze the effects of stress on the photosynthetic metabolism and its adjustability in response to changes in environmental factors. Techniques that provide information related to photosynthesis stages allow an analysis of the factors involved in regulating the use of light energy and electron transport in addition to the biochemical metabolism of carbon assimilation.

The kinetics of chlorophyll $a$ fluorescence is sensitive to environmental stresses. Even small changes in the structure and functioning of the photosynthetic apparatus may be easily detected by a proper analysis (STRASSER et al., 2004). Defined by Lavorel (1975) as the reissuance of light by excited chlorophyll molecules, fluorescence is the result of loss of photon energy absorbed by the chlorophyll $a$ not used during the photochemical stage of the production of ATP and
NADPH. Chlorophyll $a$ fluorescence can be induced by continuous signals (transient fluorescence) or by modulated excitation (STRASSER et al., 2004).

The analysis of the kinetics of fluorescence emission was improved due to the development of the JIP test. It analyzes the fast increase in OJIP fluorescence considering multiple variables (STRASSER; STRASSER, 1995) and allows quantifying in vivo the energy flows that pass through photosystems, in addition to evaluating the photosynthetic performance of plants and analyzing the function of PSII (YUSUF et al., 2010). It thus reflects the rate of electron transport flow inside thylakoid membranes, the subsequent operation of the ferredoxinNADP oxidoreductase and the Calvin cycle (SZILVIA et al., 2007). When transient curves are normalized and subtracted, the kinetic difference reveals bands that are normally hidden between stages $\mathrm{O}, \mathrm{J}$, I and P (YUSUF et al., 2010). As an example, the appearance of the positive $-\mathrm{K}$ band reflects the inactivation of the evolution complex of oxygen, and the -L band is indicative of the degree of clustering of PSII units. It may be positive or negative (STRASSER; STIRBET, 1998).

In this context, the objective of this study was to evaluate the daytime variations of chlorophyll $a$ fluorescence in Gallesia integrifolia seedlings indicating possible photoprotection mechanisms.

\section{MATERIALS AND METHODS}

Gallesia integrifolia (Spreng.) Harms seeds, collected in Ibaté, São Paulo (SP) state, were placed to germinate in plastic pots with a $3 \mathrm{~L}$ capacity containing soil as substrate, and kept in a greenhouse with water control whenever necessary. After 120 days after emergence, chlorophyll $a$ fluorescence measurements were performed at one-hour intervals during an eighthour period starting at 07:30.

Throughout the experimental period, the temperature (in ${ }^{\circ} \mathrm{C}$ ) and the photosynthetically active radiation (PAR, 
expressed in $\mu \mathrm{mol} \mathrm{m} \mathrm{m}^{-2} \mathrm{~s}^{-1}$ ) were measured along with fluorescence variables. Temperature and PAR data were directly obtained using a FMS2 portable fluorometer (Hansatech Instruments), which has an automated system for temperature and PAR readings. The evaluations of chlorophyll $a$ transient and modulated fluorescence were made in the fully expanded top leaf. The experiment was conducted in a completely randomized design with one plant as the experimental unit and 10 replications.

The transient chlorophyll $a$ fluorescence was measured using a Handy-PEA portable fluorometer (Hansatech Instruments). It was induced by red light at approximately $3,000 \mu \mathrm{mol} \mathrm{m} \mathrm{m}^{-2} \mathrm{~s}^{-1}$ and analyzed by JIP test (STRASSER et al., 2000; 2004; TSIMILLIMICHAEL; STRASSER, 2008) using fluorescence intensity measurements at $50 \mu$ s (initial fluorescence, $\mathrm{F}_{0}$ ), $2 \mathrm{~ms}$ (fluorescence at point $\mathrm{J}, \mathrm{F}_{\mathrm{J}}$ ), $30 \mathrm{~ms}$ (fluorescence at Point $\left.I, F_{I}\right)$ and maximum fluorescence $\left(F_{M}\right)$. For each variable, the values were normalized using as reference the respective control (measurements at 07:30). The normalization of fluorescence variables consists in transforming data of the control measurement in unit values and the other data in relation to this value.

To compare the events reflected in the phases OJ, OI and IP, transient curves were normalized as relative variable fluorescence: $\mathrm{W}_{\mathrm{OK}}=\left(\mathrm{F}_{\mathrm{t}}-\mathrm{F}_{0}\right) /\left(\mathrm{F}_{\mathrm{K}}-\mathrm{F}_{0}\right), \mathrm{W}_{\mathrm{OJ}}=$ $\left(\mathrm{F}_{\mathrm{t}}-\mathrm{F}_{0}\right) /\left(\mathrm{F}_{\mathrm{J}}-\mathrm{F}_{0}\right), \mathrm{W}_{\mathrm{OI}}=\left(\mathrm{F}_{\mathrm{t}}-\mathrm{F}_{0}\right) /\left(\mathrm{F}_{\mathrm{I}}-\mathrm{F}_{0}\right)$ and $\mathrm{W}_{\mathrm{IP}}=\left(\mathrm{F}_{\mathrm{t}}-\mathrm{F}_{\mathrm{I}}\right) /$ $\left(\mathrm{F}_{\mathrm{M}}-\mathrm{F}_{\mathrm{I}}\right)$ (TSIMILLI-MICHAEL; STRASSER, 2008). To analyze the kinetic difference, the differences among relative variable fluorescence curves were calculated $\left(\Delta \mathrm{W}=\mathrm{W}_{\text {treatment }}-\mathrm{W}_{\text {control }}\right)$, a procedure that reveals bands usually not identified between the stages $\mathrm{O}$ and $\mathrm{J}$ of the relative variable fluorescence curves.

The modulated fluorescence was measured using a portable fluorometer (FMS2, Hansatech Instruments). The readings were taken at the same time and in the same leaf as used for transient fluorescence measurements. The initial fluorescence $\left(\mathrm{F}_{0}\right)$ was measured at a low-intensity modulated light $\left(<0.1 \mu \mathrm{mol} \mathrm{m} \mathrm{m}^{-2} \mathrm{~s}^{-1}\right)$. The maximum fluorescence was determined after applying a saturating pulse $\left(3,000 \mu \mathrm{mol} \mathrm{m} \mathrm{m}^{-2} \mathrm{~s}^{-1}\right)$ with a duration of 1 second in leaves previously adapted to dark for 30 minutes (STRASSER et al., 2004). After the initial measurements were made, the leaves were continuously illuminated with an actinic light intensity of $200 \mu \mathrm{mol}$ $\mathrm{m}^{-2} \mathrm{~s}^{-1}$. This light was applied until reaching the terminal fluorescence or the steady-state (PS). Then, a second saturating pulse at $3,000 \mu \mathrm{mol} \mathrm{m} \mathrm{m}^{-2} \mathrm{~s}^{-1}$ was used to determine the maximal fluorescence in an adapted to light state $\left(\mathrm{F}_{\mathrm{M}}\right.$ '). After the actinic light was switched off, the minimum fluorescence in an adapted to light state $\left(\mathrm{F}_{0}{ }^{\prime}\right)$ was measured by the leaf illumination with red light for 1 second. Using the fluorescence levels measured in adapted to light and dark states, the following variables were calculated: a) effective photochemical efficiency of PSII when all PSII reaction centers were open $\left.\left(\mathrm{F}_{\mathrm{V}}, \mathrm{F}_{\mathrm{M}}{ }^{\prime}\right) ; \mathrm{b}\right)$ actual photochemical efficiency of PSII $\left.\left[\varphi_{\mathrm{PSII}}=\left(\mathrm{F}_{\mathrm{M}}{ }^{\prime}-\mathrm{PS}\right) / \mathrm{F}_{\mathrm{M}}{ }^{\prime}\right] ; \mathrm{c}\right)$ coefficient of photochemical quenching $\left[\mathrm{qP}=\left(\mathrm{F}_{\mathrm{M}}{ }^{\prime}-\mathrm{PS}\right) /\left(\mathrm{F}_{\mathrm{M}}{ }^{\prime}-\mathrm{F}_{0}{ }^{\prime}\right)\right]$ (GENTY et al., 1989); d) coefficient of non-photochemical quenching $\left[\mathrm{qNP}=\left(\mathrm{F}_{\mathrm{M}}-\mathrm{F}_{\mathrm{M}}{ }^{\prime}\right) /\left(\mathrm{F}_{\mathrm{M}}-\mathrm{F}_{0}\right)\right]($ SCHREIBER et al., 1986).

\section{RESULTS}

Figure 1 shows the variation of temperature and the photosynthetically active radiation during the experimental period. A lower PAR was observed in early morning: $181 \mu \mathrm{mol} \mathrm{m} \mathrm{m}^{-2} \mathrm{~s}^{-1}$. With the course of the day, the photon flux density increased, with a maximum peak of $1,928 \mu \mathrm{mol} \mathrm{m}^{-2} \mathrm{~s}^{-1}$ at 12:30 and a subsequent gradual decrease until the end of the day. A similar behavior could be observed for temperature, but with a lower range of variation $\left(25-42^{\circ} \mathrm{C}\right.$ at $07: 30$ and $12: 30$, respectively).

In relation to transient chlorophyll $a$ fluorescence, the analysis of the JIP test evidenced greater values of flow absorption per reaction center (ABS/RC) after the period with the greatest radiation and temperature, i.e., after 12:30 without, however, modifying the capture flow by reaction center $\left(\mathrm{TR}_{0} / \mathrm{RC}\right)$ at the different times. The electron transport flow ( $\left.\mathrm{ET}_{0} / \mathrm{RC}\right)$ decreased at 12:30, unlike the other studied intervals. The reduction flow by reaction center $\left(\mathrm{RE}_{0} / \mathrm{RC}\right)$ kept high values during the course of the day. A similar behavior was found for dissipation flow $\left(\mathrm{DI}_{0} / \mathrm{RC}\right)$, but with higher values (Figure 2).

The parameter $\mathrm{PI}_{\mathrm{ABS}}$ showed decreasing values, especially after the period with the greatest radiation and temperature. Regarding $\mathrm{PI}_{\text {TOTAL}}$, the decrease in values was lower. However, values higher than the control were found at 09:30.

The analysis of the kinetic difference of fluorescence emission curves between stages $(50 \mu \mathrm{s}), \mathrm{K}(300 \mu \mathrm{s})$ (Figure $3 \mathrm{C})$ and $(50 \mu \mathrm{s})$ and $\mathrm{J}(2 \mu \mathrm{s})$ (Figure $3 \mathrm{D})$ allowed identifying positive $-\mathrm{L}$ and $-\mathrm{K}$ bands, respectively, at

Revista Árvore, Viçosa-MG, v.40, n.6, p.1023-1030, 2016 


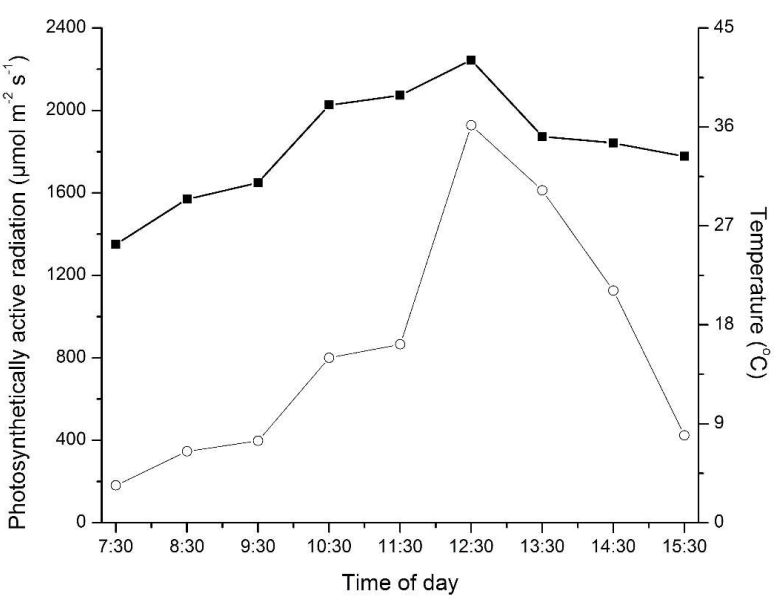

Figure 1 - Photosynthetically active radiation (PAR, $\mu \mathrm{mol}$ $\left.\mathrm{m}^{-2} \mathrm{~s}^{-1},--\mathrm{O}--\right)$ and temperature $\left(\mathrm{T},{ }^{\circ} \mathrm{C}--\mathbf{-}--\right)$ monitored during the experimental period.

Figura 1 - Radiação fotossinteticamente ativa (RAF, pmol $\left.m^{-2} \mathrm{~s}^{-1},--\mathrm{O}--\right)$ e temperatura $\left(T,{ }^{o} \mathrm{C}\right.$, monitoradas durante o periodo experimental.

approximately 150 and $300 \mu$ s. The -L band had the greatest amplitude between 14:30 and 15:30. A similar behavior could be observed for $\Delta \mathrm{W}_{\mathrm{OJ}}$ with the emergence of the $-\mathrm{K}$ band. Thus, the overall reduction rate of final electron acceptors was higher (less time to reach VIP $=0.5$ ) at 14:30, unlike the lower decrease rate of the final acceptors of PSI at 07:30.

Regarding the normalization of fluorescence emission curves between the stages $\mathrm{O}(50 \mu \mathrm{s})$ and $\mathrm{I}(30 \mathrm{~ms})$ (Figure $3 \mathrm{E}, \mathrm{F})$ as variable fluorescence $\left(\mathrm{W}_{\mathrm{OI}}\right)$ associated with the interpretation of the standardization of the variable fluorescence between the stages $\mathrm{O}$ and I and with values higher or equal to $1\left(\mathrm{~W}_{\mathrm{OI}} \geq 1\right)$, there is an increase in the amplitude of the curve around $2 \mathrm{~ms}$ (point $\mathrm{J}$ ) for the time interval between 12:30 and 14:30. Regarding the variable relative fluorescence between the stages I and P $\left(\mathrm{W}_{\mathrm{IP}}\right)$ (Figure $3 \mathrm{G}$ ), there is a longer time to reach $\mathrm{W}_{\mathrm{IP}}=0.5$ during the first hour of experiment.

Figure 4 shows the values for modulated fluorescence. The ratio $F_{v}{ }^{\prime} / F_{M}$ ' and $\varphi_{P S I I}$ showed a similar behavior for both parameters, where the lowest values were determined at 07:30, with a slight increase after this time and a further decrease at 12:30, period corresponding to the highest temperature and radiation. The parameters that represent the non-photochemical dissipation ( $\mathrm{qP}$ and $\mathrm{qNP}$ ) showed higher values during

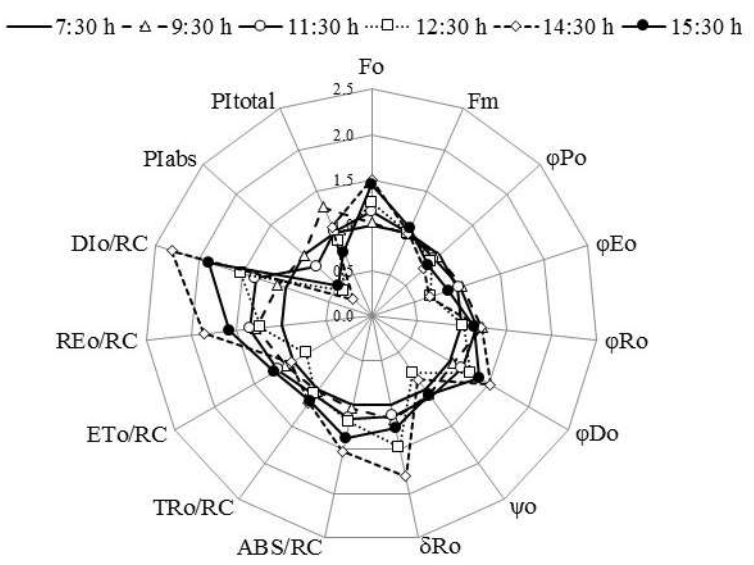

Figure 2 - JIP test parameters of Gallesia integrifolia plants evaluated during one-hour intervals for eight hours. For each parameter, the values were normalized using as a reference the value for 07:30. Only the most representative times are shown.

Figura 2-Parâmetros do Teste JIP em plantas de Gallesia integrifolia realizadas em intervalos de uma hora, durante o período de oito horas. Para cada parâmetro os valores foram normalizados, utilizando como referência o valor das 7:30h. Estão apresentados apenas os horários mais representativos.

the low radiation period, i.e., at early morning. The photochemical quenching ( $\mathrm{qP}$ ) did not change during the course of the day. For the coefficient of nonphotochemical quenching (qNP), high values were identified at 07:30 with a marked decrease up to 10:30. After such period, the values were stable.

\section{DISCUSSION}

From the transient chlorophyll $a$ fluorescence, the structure and the conformation of the electron transport chain can be analyzed by a representation of an energy flow cascade. The increase in $\mathrm{DI}_{0} / \mathrm{RC}$ values in the intervals between 12:30 and 15:30 shows that most of the energy absorbed by PSII was dissipated as heat or fluorescence, decreasing the percentage of energy channeled to reaction centers $\left(\mathrm{TR}_{0} / \mathrm{RC}\right)$ for conversion into energy capable of reducing quinone $A\left(Q_{A}\right)$, thus reducing the other carriers in the electron transport chain $\left(\mathrm{ET}_{0} / \mathrm{RC}\right.$ and $\left.\mathrm{RE}_{0} / \mathrm{RC}\right)$. Generally, under a low light intensity, most of the light absorbed by the chlorophylls can be used in photosynthesis photochemical processes (high photosynthetic efficiency). However, at a relatively high-intense light, only part of the absorbed light may be used (LONG 

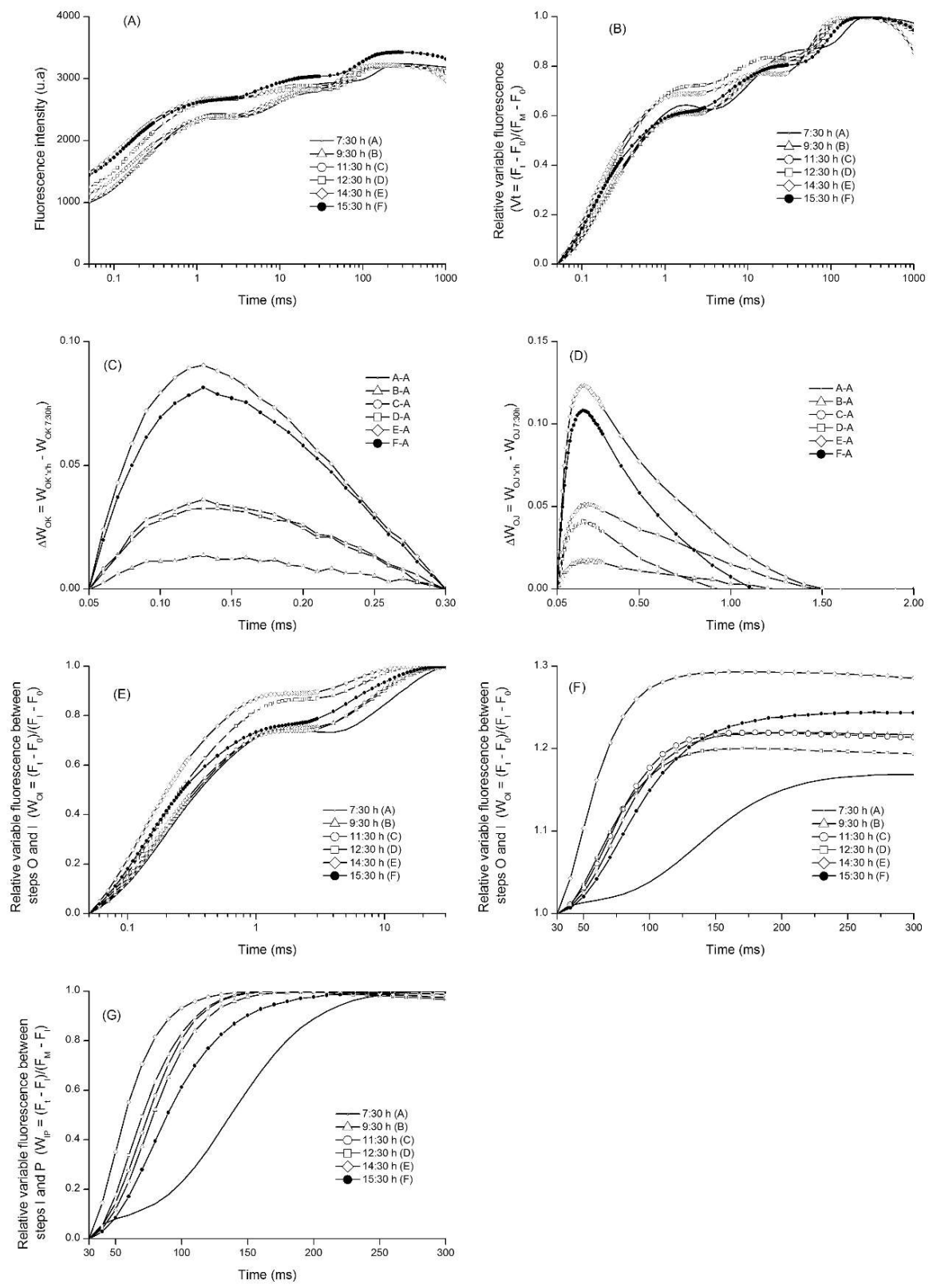

Figure 3 - Evaluation of transient chlorophyll $a$ fluorescence of Gallesia integrifolia leaves performed at one-hour intervals for eight hours. (A) Intensity of fluorescence; (B) relative variable fluorescence; (C) kinetic difference of $\mathrm{W}_{\mathrm{OK}}$ $\left[\Delta \mathrm{V}_{\mathrm{OK}}=\mathrm{V}_{\mathrm{OK}}\right.$ treatament $-\mathrm{V}_{\mathrm{OK}}$ control) $]$; (D) kinetic difference of $\mathrm{W}_{\mathrm{OJ}}\left[\Delta \mathrm{V}_{\mathrm{OJ}}=\left(\mathrm{V}_{\text {OJtreatament }}-\mathrm{V}_{\text {OJcontrol }}\right)\right]$; (E) variable fluorescence between the points $\mathrm{O}$ and $\mathrm{I}\left[\mathrm{W}_{\mathrm{OL}}=\left(\mathrm{F}_{\mathrm{t}}-\mathrm{F}_{0}\right) /\left(\mathrm{F}_{\mathrm{I}}-\mathrm{F}_{0}\right)\right] ;(\mathrm{F}) \mathrm{W}_{\mathrm{OI}}$ between 30 and $300 \mu \mathrm{s} ;(\mathrm{G})$ variable fluorescence between the points I and $\mathrm{P}\left[\mathrm{W}_{\mathrm{IP}}=\left(\mathrm{F}_{\mathrm{t}}-\mathrm{F}_{\mathrm{I}}\right) /\left(\mathrm{F}_{\mathrm{P}}-\mathrm{F}_{\mathrm{I}}\right)\right]$. Only the most representative times are shown.

Figura 3 - Fluorescência transiente da clorofila a de folhas de plantas Gallesia integrifolia realizada em intervalos de uma hora, durante o periodo de oito horas. (A) Intensidade de fluorescência; (B) fluorescência variável relativa; (C) diferença cinética de WOK $\left[\Delta V_{O K}=V_{O K}\right.$ tratamento $-V_{O K}$ controle)]; (D) diferença cinética de WOJ [ $\triangle V O J$ $\left.=\left(V_{\text {OJtratamento }}-V_{\text {OJcontrole }}\right)\right] ;$ (E) fluorescência variável entre os pontos $O$ e I $\left[W_{O I}=\left(F_{t}-F_{0}\right) /\left(F_{I}-F_{0}\right)\right] ;(F) W_{O I}$ no tempo entre 30 e $300 \mu \mathrm{s} ;(G)$ fluorescência variável entre os pontos I e $P\left[W_{I P}=\left(F_{t}-F_{P}\right) /\left(F_{P}-F_{P}\right)\right]$. Estão apresentados apenas os horários mais representativos. 


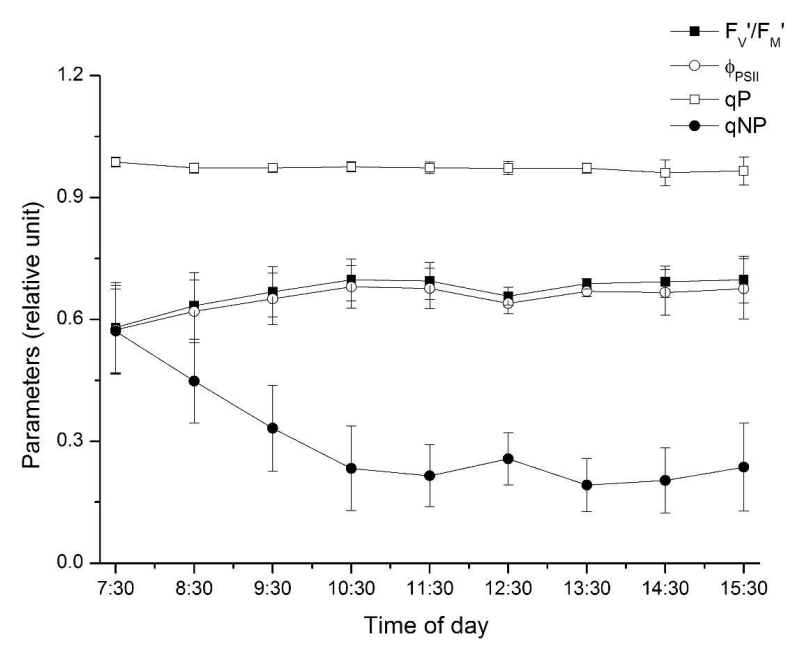

Figure 4 - Fluorescence modulated chlorophyll a plant Gallesia integrifolia at intervals of one hour during the period of eight hours. Maximum photochemical quantum yield (FV'/FM'); current photochemical efficiency of PSII ( $\varphi$ PSII) in state adapted the light; extinction coefficient of photochemical (qP) and extinction coefficient non-photochemical quenching (qNP).

Figura 4 -Fluorescência modulada da clorofila a de plantas de Gallesia integrifolia em intervalos de uma hora, durante o período de oito horas. Rendimento quântico fotoquímico máximo $\left(F V^{\prime} / F M^{\prime}\right)$; eficiência fotoquímica atual do FS II ( $\varphi$ PSII) em estado adaptado a luz; coeficiente de extinção fotoquímico $(q P)$ e coeficiente de extinção não-fotoquimico $(q N P)$.

et al., 1994). Moreover, under high light conditions, the antenna system presents an excessive influx of photons to the PSII reaction center (HORTON et al., 1996). This causes a decrease in electron transport as a protection mechanism. However, there are separate mechanisms to deal with light stresses such as changes in fluorescence parameters related to the size of the PSII antenna (LAZÁR, 2006).

Regarding the performance indexes $\mathrm{PI}_{\mathrm{ABS}}$ and $\mathrm{PI}_{\mathrm{TOTAL}}$, low values in higher radiation and temperature intervals can be explained by the behavior of $\mathrm{RC} / \mathrm{ABS}$ ratio and the $\left[\varphi_{\mathrm{Po}} /\left(1-\varphi_{\mathrm{Po}}\right)\right]$ ratio, which were the components that contributed the most to the decrease of $\mathrm{PI}_{\mathrm{ABS}}$ during the course of the day. Thus, it can be inferred that the increase in radiation associated with the increase in temperature causes a decrease in the number of active RCs of PSII, inactivation of RCs and efficiency of redox reactions in PSII.
The results for $\Delta \mathrm{W}_{\mathrm{OK}}$ are explained by the amplitude of the -L band. The higher the amplitude, the lower the connectivity or grouping of PSII units, a fact observed between 12:30 and 14:30. The emergence of the - $\mathrm{K}$ band, which describes the balance established between electron transports, is associated with the inactivation of the oxygen evolution complex. PSII is considered more susceptible to high temperatures when compared to the PSI, as it presents the most vulnerable donor side in the electron transport chain (WEN et al., 2005). In this context, the oxygen evolution complex is among photosynthetic processes noticeably affected by the emergence of the $-\mathrm{K}$ band. Such an event has been attributed to a thermal stress at $44-48^{\circ} \mathrm{C}$ (LAZÁR, 2006). This stress results in an imbalance in the electron flow, causing the acceptor side of the electron flow rate to exceed the donor side of the electron flow rate of PSII (LAZÁR, 2006).

By analyzing the modulated fluorescence, the ratio $\mathrm{F}_{\mathrm{v}}$ '/ $\mathrm{F}_{\mathrm{M}}$ ' and the $\varphi$ PSII represent, respectively, the maximum photochemical quantum yield and the current photochemical yield adapted to light. The ratio $\mathrm{F}_{\mathrm{v}}$ '/ $\mathrm{F}_{\mathrm{M}}$ ' provides an estimate of the maximum photochemical efficiency of PSII samples adapted to light when $\mathrm{Q}_{\mathrm{A}}$ is oxidized. During the evaluation periods, there was a higher yield at 11:30, indicating that the fraction of light absorbed by the chlorophyll, associated with the activity of PSII, was effectively used in photochemical processes. The decrease in the parameters related to photochemical efficiency in the subsequent period (12:30) can be linked to the photoinhibition (LONG et al., 1994) caused by the high PAR (Figure 1), which in turn coincides with higher values of non-photochemical quenching coefficient during the same period (Figure 4).

The parameters representing photochemical dissipation with higher values during the low radiation period, i.e., at early morning, are related to the inactive state of the enzymes of the $\mathrm{CO}_{2}$ reduction cycle (Calvin Cycle) or to the presence of inhibitors of Rubisco activity (BUCHANAN, 1980). In this context, there is an accumulation of reducing power $\left(\mathrm{NADPH}_{2}\right)$ and ATP when the biochemical phase is inhibited or with a low activity. This caused a restriction in the electron transport chain and an increase in energy dissipation absorbed as heat.

\section{CONCLUSIONS}

It can be concluded that Gallesia integrifolia decreases its photochemical activity with the increase in the photosynthetic active radiation, demonstrating 
a photoinhibitory effect under high irradiance conditions, but without irreversible damage to the photosynthetic apparatus.

\section{ACKNOWLEDGEMENTS}

The authors would like to thank the Coordination for the Improvement of Higher Education Personnel (CAPES) and the National Council for Scientific and Technological Development (CNPq).

\section{REFERENCES}

BUCHANAN, B.B. Role of light in the regulation of chloroplast enzymes. Annual Review of Plant Physiology, v.31, p.341-394, 1980.

FRANCO, A.C. Estratégias funcionais de plantas lenhosas das savannas do Brasil Central: relação ao déficit hídrico e ao regime luminoso. In: CABRERA, H.M. Fisiologia ecológica em plantas: mecanismos y respuestas a estres em los ecosistemas. Valparaiso: APHA, 2004. p.173-188.

GENTY, B.; BRIANTAIS, J.M.; BAKER, N.R. The relationship between the quantum yield of photosynthetic electron transport and quenching of chlorophyll fluorescence. Biochimica et Biophysica Acta. v.990, p.87-92, 1989.

HORTON, P.; RUBAN, A.V.; WALTERS, R.G. Regulation of light harvesting in green plants, Annual Review of Plant Physiology, v.47, p.655-684, 1996.

HUSSNER, A.; HOFSTRA, D.; JAHNS, P. Diurnal courses of net photosynthesis and photosystem II quantum efficiency of submerged Lagarosiphon major under natural light conditions. Flora, . v.206, p.904-909, 2011.

LAVOREL, J. Luminescence. In: GOVINDJEE. Bioenergetics of Photosynthesis. New York: Academic Press, 1975. p.223-317.

LAZÁR, D. The polyphasic chlorophyll $a$ fluorescence rise measured under high intensity of exciting light. Functional Plant Biology, v.33, p.9-30, 2006.

LONG, S.P.; HUMPHRIES, S.; FALKOWSKI, P.G. Photoinhibition of photosynthesis in nature. Annual Review of Plant Physiology and Plant Molecular Biology, v.45, p.633$662,1994$.

LORENZI, H. Árvores brasileiras: manual de identificação e cultivo de plantas arbóreas nativas do Brasil. Nova Odessa: Editora Plantarum. 1992. 382 p.

SCHREIBER, U; SCHLIWA, U; BILGER, W. Continuous recording of photochemical and nonphotochemical chlorophyll fluorescence quenching with a new type of modulation fluorometer. Photosynthesis Research, Dordrecht, v.10, p.51-62, 1986.

STRASSER, B.J; STRASSER, R.J. Measuring fast fluorescence transients to address environmental questions: The JIP-test. In: MATHIS P.

Photosynthesis: From Light to Biosphere. Dordrecht: Kluwer Academic Publ. 1995. p. 977-980.

STRASSER, R.J; SRIVASTAVA, A; TSIMILLIMICHAEL, M. Analysis of the chlorophyll $a$ fluorescence transient. In: PAPAGEORGIOU G, GOVINDJEE. Advances in Photosynthesis and Respiration Chlorophyll Fluorescence a Signature of Photosynthesis, The Netherlands: Kluwer Academic Publishers, 2004. p.321-362.

STRASSER, R.J; SRIVASTAVA, A; TSIMILLIMICHAEL, M. The fluorescence transient as a tool to characterize and screen photosynthetic samples. In: YUNUS M, PATHRE U, MOHANTY P. Probing Photosynthesis: Mechanisms, Regulation and Adaptation. New York: Tayor and Francis, 2000. p. 445-483.

STRASSER, R.J; STIRBET, A.D. Heterogeneity of Photosystem II probed by the numerically simulated chlorophyll a fluorescence rise (O-J-I-P). Mathematics and Computers in Simulation, Amsterdam,v.48, p.3-9, 1998.

SZILVIA, Z.T; SCHANSKER, G; GARAB, G; STRASSER, R.J. Photosynthetic electron transport activity in heat-treated barley leaves: The role of internal alternative electron donors to photosystem II. Biochimica et Biophysica Acta, Amsterdam, v. 1767, p.295-305, 2007.

TSIMILLI-MICHAEL, M; STRASSER, R.J. In vivo assessment of plants vitality: applications in detecting and evaluating the impact of

Revista Árvore, Viçosa-MG, v.40, n.6, p.1023-1030, 2016 
Mycorrhization on host plants. In: VARMA, A. Mycorrhiza. Uttar Pradesh: Springer, 2008. p.679-703.

WEN, X; GONG, H; LU. C. Heat stress induces a reversible inhibition of electron transport at the acceptor side of photosystem II in a cyanobacterium Spirulina platensis. Plant Science, Limerick, v.168, p.1471-1476, 2005.
YUSUF, M.M.; KUMAR, D.; RAJWANSHI, R.; STRASSER, R.J., TSIMILLIMICHAEL, M.; GOVINDJEE; SARIN, N.B. Overexpression of $\gamma$ tocopherol methyl transferase gene in transgenic Brassica juncea plants alleviates abiotic stress: Physiological and chlorophyll fluorescence measurements. Biochimica et Biophysica Acta, Amsterdam, v. 1797, p.1428-1438, 2010. 